National and Global Petroleum Assessment

\title{
Assessment of Continuous Oil and Gas Resources in the Pannonian Basin Province, Hungary, 2016
}

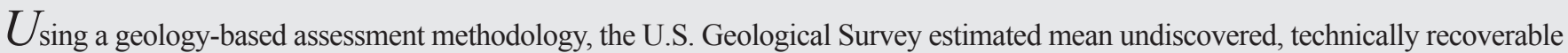
continuous resources of 119 million barrels of oil and 944 billion cubic feet of gas in the Hungarian part of the Pannonian Basin Province.

\section{Introduction}

The U.S. Geological Survey (USGS) completed an assessment of undiscovered, technically recoverable continuous oil and gas resources within the Hungarian part of the Pannonian Basin Province (fig. 1). The Neogene Pannonian Basin Province is a structurally complex region surrounded by the eastern Alps, west Carpathians, Munții Apuseni, outer Carpathians, south Carpathians, and Dinaric Alps fold belts (Royden, 1988; Dolton, 2006; Tari and Horváth, 2006; Matenco and Radivojević, 2012). Badics and Veto (2012) summarized all of the pertinent geologic and geochemical data on potential continuous (shale oil and shale gas) reservoirs in the Hungarian part of the Pannonian Basin Province. Badics and Veto (2012) concluded that the most viable continuous reservoirs are within the Triassic Kossen Shale, the Lower Jurassic Mecsek Unit, and the lower Oligocene Tard Shale. The purpose of this study is to estimate potential volumes of recoverable continuous oil and gas resources within these three stratigraphic intervals.

\section{Total Petroleum Systems and Assessment Units}

For the Pannonian Basin Province, the USGS defined a Triassic Kossen Total Petroleum System (TPS) with the Triassic Kossen Shale Oil Assessment Unit (AU) and the Triassic Kossen Shale Gas AU, a Lower Jurassic TPS with the Lower Jurassic Mecsek Tight Gas AU, and a Lower Oligocene TPS with the Lower Oligocene Tard Shale Oil AU and the Lower Oligocene Tard Shale Gas AU within this TPS (fig. 1). The areas of these AUs reflect the mapping of Badics and Veto (2012).

The geologic model for the Triassic Kossen Shale Oil AU and the Triassic Kossen Shale Gas AU is for some portion of oil and gas generated from organic-rich shales (as much as 19 weight percent total organic carbon; Clayton and Koncz, 1994; Badics and Veto, 2012) to have been retained within the shales. The geologic model for the Lower Jurassic Mecsek Unit is for gas generated from coals and carbonaceous

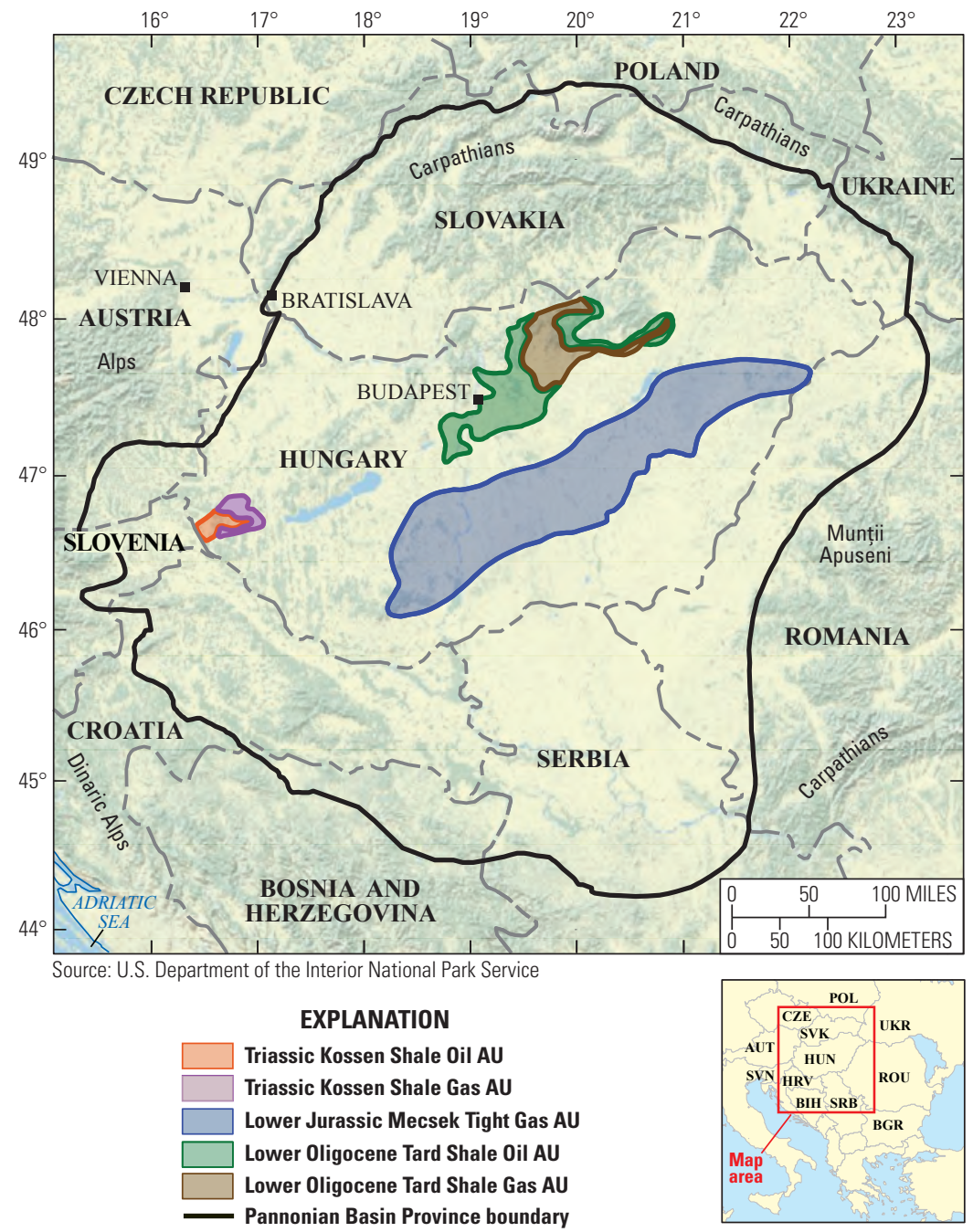

Figure 1. Location of the Pannonian Basin Province and the five continuous assessment units (AUs) defined in this study.

shales to have migrated locally into tight reservoirs, forming a tight-gas accumulation. The geologic model for the Lower Oligocene Tard Shale Oil AU and Lower Oligocene Tard Shale Gas AU is for some portion of the generated oil and gas to have been retained within Tard shales.

Assessment input data for five continuous assessment units are shown in table 1 . Well drainage areas, estimated ultimate recoveries, and success ratios are taken from U.S. shale-oil, shale-gas, and tight-gas analogs. 


\section{Undiscovered Resources Summary}

The USGS quantitatively assessed undiscovered, technically recoverable continuous oil and gas resources within five AUs in the Hungarian part of the Pannonian Basin Province (table 2). The total means for continuous resources are 119 million barrels of oil (MMBO) with an F95-F5 range from 0 to 299 MMBO, 944 billion cubic feet of gas (BCFG) with an F95-F5 range from 0 to 3,239 BCFG, and 13 million barrels of natural gas liquids (MMBNGL) with an F95-F5 range from 0 to 45 MMBNGL.

Table 1. Key assessment input data for five continuous assessment units in the Hungarian part of the Pannonian Basin Province. [\%, percent; EUR, estimated ultimate recovery per well; MMBO, million barrels of oil; BCFG, billion cubic feet of gas. Well drainage areas, EURs, and well success ratios are from U.S. shale-oil, shale-gas, and tight-gas analogs. The average EUR input is the minimum, median, maximum, and calculated mean. Shading indicates not applicable]

\begin{tabular}{|c|c|c|c|c|c|c|c|c|}
\hline \multirow{2}{*}{$\begin{array}{l}\text { Assessment input data- } \\
\text { Continuous assessment units (AUs) }\end{array}$} & \multicolumn{4}{|c|}{ Triassic Kossen Shale Oil AU } & \multicolumn{4}{|c|}{ Triassic Kossen Shale Gas AU } \\
\hline & Minimum & Mode & Maximum & Calculated mean & Minimum & Mode & Maximum & Calculated mean \\
\hline Potential production area of AU (acres) & 480 & 60,000 & 120,000 & 60,160 & 480 & 50,000 & 100,000 & 50,160 \\
\hline Average drainage area of wells (acres) & 40 & 80 & 120 & 80 & 80 & 120 & 160 & 120 \\
\hline Success ratios $(\%)$ & 10 & 50 & 90 & 50 & 10 & 50 & 90 & 50 \\
\hline Average EUR (MMBO, oil; BCFG, gas) & 0.04 & 0.08 & 0.2 & 0.086 & 0.1 & 0.3 & 0.7 & 0.319 \\
\hline AU probability & 0.9 & & & & 0.9 & & & \\
\hline Assessment input data- & \multicolumn{4}{|c|}{ Lower Jurassic Mecsek Tight Gas AU } & \multicolumn{4}{|c|}{ Lower Oligocene Tard Shale Oil AU } \\
\hline Continuous assessment units (AUs) & Minimum & Mode & Maximum & Calculated mean & Minimum & Mode & Maximum & Calculated mean \\
\hline Potential production area of AU (acres) & 480 & $1,300,000$ & $4,000,000$ & $1,766,827$ & 480 & 408,000 & 816,000 & 408,160 \\
\hline Average drainage area of wells (acres) & 40 & 80 & 120 & 80 & 40 & 80 & 120 & 80 \\
\hline Success ratios $(\%)$ & 10 & 50 & 90 & 50 & 10 & 50 & 90 & 50 \\
\hline Average EUR (BCFG, gas; MMBO, oil) & 0.04 & 0.08 & 0.4 & 0.098 & 0.02 & 0.04 & 0.1 & 0.043 \\
\hline AU probability & 0.5 & & & & 0.8 & & & \\
\hline Assessment input data- & \multicolumn{4}{|c|}{ Lower Oligocene Tard Shale Gas AU } & & & & \\
\hline Continuous assessment units (AUs) & Minimum & Mode & Maximum & Calculated mean & & & & \\
\hline Potential production area of AU (acres) & 480 & 255,000 & 509,000 & 254,827 & & & & \\
\hline Average drainage area of wells (acres) & 80 & 120 & 160 & 120 & & & & \\
\hline Success ratios $(\%)$ & 10 & 50 & 90 & 50 & & & & \\
\hline Average EUR (BCFG, gas) & 0.04 & 0.1 & 0.8 & 0.138 & & & & \\
\hline AU probability & 0.8 & & & & & & & \\
\hline
\end{tabular}

Table 2. Assessment results for five continuous assessment units in the Hungarian part of the Pannonian Basin Province.

[MMBO, million barrels of oil; BCFG, billion cubic feet of gas; NGL, natural gas liquids; MMBNGL, million barrels of natural gas liquids. Results shown are fully risked estimates. For gas accumulations, all liquids are included in the NGL category. F95 represents a 95-percent chance of at least the amount tabulated; other fractiles are defined similarly. Fractiles are additive under the assumption of perfect positive correlation. Shading indicates not applicable]

\begin{tabular}{|c|c|c|c|c|c|c|c|c|c|c|c|c|c|c|}
\hline \multirow{3}{*}{$\begin{array}{l}\text { Total petroleum system and } \\
\text { assessment units (AUs) }\end{array}$} & \multirow{3}{*}{$\begin{array}{c}\text { AU } \\
\text { probability }\end{array}$} & \multirow{3}{*}{$\begin{array}{c}\text { Accumulation } \\
\text { type }\end{array}$} & \multicolumn{12}{|c|}{ Total undiscovered resources } \\
\hline & & & \multicolumn{4}{|c|}{ Oil (MMBO) } & \multicolumn{4}{|c|}{ Gas (BCFG) } & \multicolumn{4}{|c|}{ NGL (MMBNGL) } \\
\hline & & & F95 & $\mathrm{F} 50$ & F5 & Mean & F95 & F50 & F5 & Mean & F95 & $\mathrm{F} 50$ & $\mathrm{~F} 5$ & Mean \\
\hline \multicolumn{15}{|c|}{ Triassic Kossen Total Petroleum System } \\
\hline Triassic Kossen Shale Oil AU & 0.9 & Oil & 0 & 26 & 70 & 30 & 0 & 51 & 145 & 59 & 0 & 1 & 3 & 1 \\
\hline Triassic Kossen Shale Gas AU & 0.9 & Gas & & & & & 0 & 54 & 140 & 60 & 0 & 1 & 3 & 1 \\
\hline \multicolumn{15}{|c|}{ Lower Jurassic Total Petroleum System } \\
\hline Lower Jurassic Mecsek Tight Gas AU & 0.5 & Gas & & & & & 0 & 0 & 2,112 & 533 & 0 & 0 & 22 & 5 \\
\hline \multicolumn{15}{|c|}{ Lower Oligocene Total Petroleum System } \\
\hline Lower Oligocene Tard Shale Oil AU & 0.8 & Oil & 0 & 79 & 229 & 89 & 0 & 152 & 476 & 178 & 0 & 3 & 10 & 4 \\
\hline Lower Oligocene Tard Shale Gas AU & 0.8 & Gas & & & & & 0 & 79 & 366 & 114 & 0 & 2 & 7 & 2 \\
\hline Total undiscovered continuous resources & & & $\mathbf{0}$ & 105 & 299 & 119 & $\mathbf{0}$ & 336 & 3,239 & 944 & $\mathbf{0}$ & 7 & 45 & 13 \\
\hline
\end{tabular}

\section{References Cited}

Badics, Balázs, and Veto, István, 2012, Source rocks and petroleum systems in the Hungarian part of the Pannonian Basin—The potential for shale gas and shale oil plays: Marine and Petroleum Geology, v. 31, no. 1, p. 53-69.

Clayton, J.L., and Koncz, Istvan, 1994, Petroleum geochemistry of the Zala Basin, Hungary: American Association of Petroleum Geologists Bulletin, v. 78, no. 1, p. 1-22.

Dolton, G.L., 2006, Pannonian Basin Province, Central Europe (Province 4808)—Petroleum geology, total petroleum systems, and petroleum resource assessment: U.S. Geological Survey Bulletin 2204-B, 47 p.

Matenco, L.C., and Radivojević, D., 2012, On the formation and evolution of the Pannonian basin — Constraints derived from the structure of the junction area between the Carpathians and Dinarides: Tectonics, v. 31, no. 6,31 p.

Royden, L.H., 1988, Late Cenozoic tectonics of the Pannonian Basin system, chap. 3 of Royden, L.H., and Horvath, Ferenc, eds., The Pannonian Basin-A study in basin evolution: American Association of Petroleum Geologists Memoir No. 45, p. $27-48$.

Tari, G.C., and Horváth, Frank, 2006, Alpine evolution and hydrocarbon geology of the Pannonian Basin—An overview, chap. 19 of Golonka, J., and Picha, F.J., eds., The Carpathians and their foreland - Geology and hydrocarbon resources: American Association of Petroleum Geologists Memoir No. 84, p. $605-618$.

\section{For More Information}

Assessment results also are available at the USGS Energy Resources Program website at https://energy.usgs.gov.

\section{Pannonian Basin Province Assessment Team}

Christopher J. Schenk, Timothy R. Klett, Phuong A. Le, Michael E. Brownfield, and Heidi M. Leathers-Miller 